\title{
The multiple Eudald Carbonell: The various roles of Catalonia's most popular archaeologist
}

\author{
Oliver Hochadel $(*)$ \\ $\left({ }^{*}\right) \quad$ Institució Milà i Fontanals, CSIC, Barcelona \\ oliver.hochadel@imf.csic.es
}

Dynamis

[0211-9536] 2013; 33 (2): 389-416

Fecha de recepción: 20 de diciembre de 2012

Fecha de aceptación: 28 de febrero de 2013

SUMMARY: 1.-Introduction - the icon of Atapuerca. 2.-The young archaeologist. 3.-The exhibition on Catalonian prehistory in 1976. 4.-Fighter against the «establishment». 5.- - Hunter of the «first European». 6.-An advocate for Spanish science. 7.-Fighter against «scientific colonialism». 8.-Communist and «agent of reflection». 9.-The media scientist. 10.-Catalanist and «interdependentist». 11.-Conclusion: from outsider to celebrity scientist.

ABSTRACT: Eudald Carbonell is mainly known for being the co-director of the Atapuerca research project, a hominid site in Northern Spain that boasts the "oldest European». In the course of his career as an archaeologist, he has become a highly visible figure, not least because of his incessant attempts to communicate his ideas to the general public. In these past four decades, Carbonell has taken on a host of diverse roles: scientific but also social and political ones. The political and scientific context of Catalonia and Spain since the early 1970s proves crucial in these activities. Carbonell's claim to belong to a «peripheral» scientific community (be it Catalan or Spanish) is a central element in the construction of these roles. At the same time, Carbonell provides an instructive example of the «medialization» of science, transforming himself from an outsider into a celebrity and ultimately into a commodity.

PALABRAS CLAVE: arqueología, papel social, identidad nacional, ciencia y medios de comunicación.

KEY WORDS: Archaeology, social role, national identity, science and the media.

\section{Introduction - the icon of Atapuerca $\left({ }^{*}\right)$}

«He is the tallest of them all and seems to be the one responsible for the work. His outfit is highly picturesque. He wears brown shorts, a khaki shirt and a sleeveless jacket of the same color full of pockets. Red socks peep out

$\left.{ }^{*}\right)$ Research for this article was supported by the following three projects: HAR2009-12918-C03-02; HAR2012-36204-C02-02 (both Ministerio de Economía y Competitividad) and 2009SGR887 (AGAUR-Generalitat de Catalunya). 
over his heavy boots, which are covered in dust. Yet what is most remarkable is his sun-hat, a true sun-helmet like the one Stewart Granger and Deborah Kerr sported in King Solomon's Mines (...) His face is tanned by the sun and a sympathetic and dense moustache covers the top of his mouth, giving him the air of an old photograph» ${ }^{1}$.

In this description Eudald Carbonell appears like a character out of a Hollywood movie. His distinctive features lend themselves to iconographic use. The man with the moustache and the sun-helmet smoking a pipe is a recurring item in the corporate image of the EIA (Equipo de Investigación de Atapuerca), at times only as a silhouette. He appears as the archetype of an archaeologist.
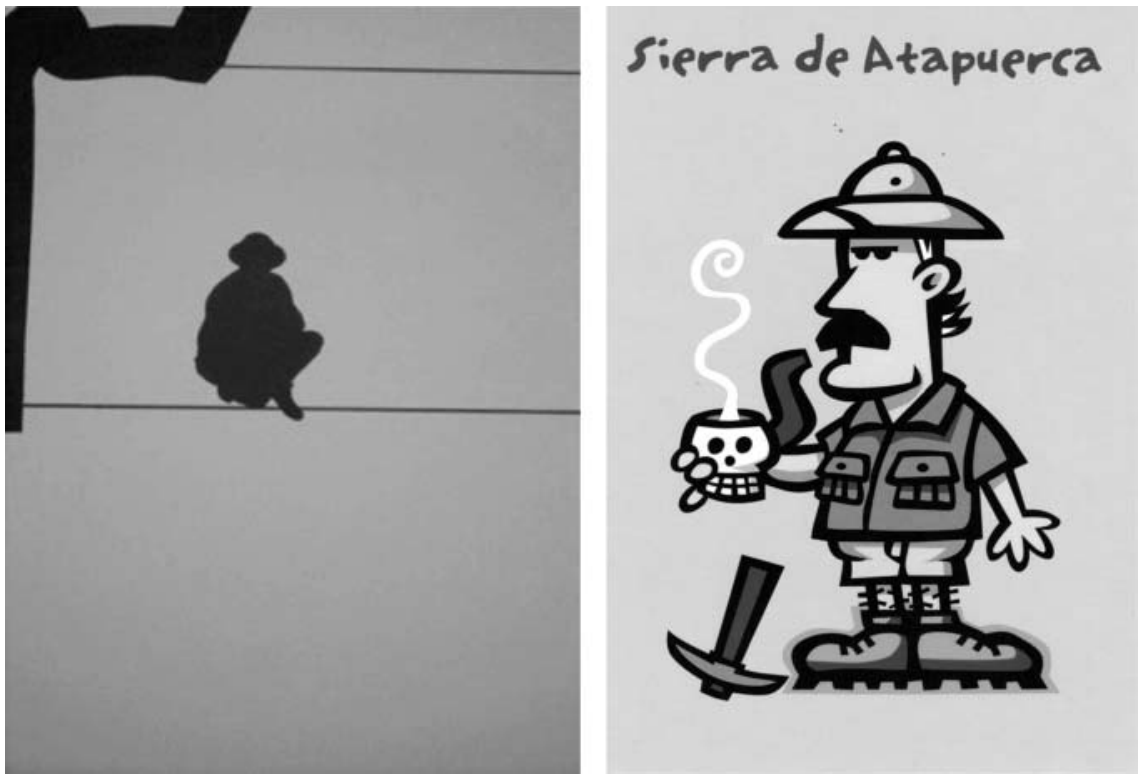

Figure 1. Eudald Carbonell has become an icon - and appears as a silhouette (left) on the walls of the Museo de la Evolución Humana in Burgos, or on postcards (right). Photo: Oliver Hochadel, Postcard: SierrActiva.

1. Bermúdez de Castro, José María et al. Hijos de un tiempo perdido. La búsqueda de nuestros orígenes. Barcelona: Ares y Mares; 2004, p. 25; also see Bermúdez de Castro, José María. Exploradores. La historia del yacimiento de Atapuerca. Barcelona: Debate; 2012, p. 24. All translations are mine. 
Carbonell wears his peculiar outfit not only while excavating. There are numerous photos showing him attending ceremonies in his short pants and heavy boots among dignitaries in suits and ties. And regardless whether the Spanish president is visiting the excavations at the Sierra de Atapuerca or whether the Spanish Queen Sofía is opening the new Museo de la Evolución Humana in Burgos. Carbonell seems to be eager to affirm his professional identity to convey a clear message: he is an archaeologist - and he is always the same no matter what the setting.

However, this paper will try to show that Carbonell actually plays a variety of different roles. To claim that nowadays a scientist has to assume a number of very diverse roles may sound trivial. For some time he or she has not only been a researcher but also an academic teacher and on occasion a public figure. More recently, the roles of the administrator, the fund-raiser and the public relations-agent have become part of the persona of the scientist. What is more, Paul Rabinow for example, has shown how in the life sciences molecular biologists have also become entrepreneurs and businessmen ${ }^{2}$.

The case of the multiple Eudald Carbonell seems to be quite different though. The roles he assumes have less to do with the «diversification» of the persona of the scientist in the late twentieth century. Carbonell's half a dozen roles need to be explained in the specific historical (political and scientific) context of Catalonia and Spain since the 1970s, in particular with respect to the situation in which archaeologists and prehistorians have found themselves in these decades. They have perceived themselves as belonging to the «periphery», trying to either attract the attention of scholars from the «center» or defending their excavation sites against «colonialists». In the case of Carbonell, it will become obvious that he constantly fashions himself as overcoming the limits of the «periphery» and successfully challenging the «center ${ }^{3}$. It seems crucial not to take these categories as historical realities but rather as rhetorical devices used to mobilize support (e.g. political or economic) and to give cohesion to newly emerging communities of scholars.

2. The classical account is Rabinow, Paul. Making PCR: A story of biotechnology. Chicago: The University of Chicago Press; 1996.

3. To look at — and to question - center-periphery relationships has become a very useful tool in the history of science: Papanelopoulou, Faidra; Nieto-Galan, Agustí; Perdiguero, Enrique, eds. Popularizing science and technology in the European periphery, 1800-2000. Aldershot: Ashgate; 2009. 
This article is by and large organized chronologically but is not intended as a biography of Carbonell. Instead we will try to describe the emergence of the different roles and their relations with each other. The roles we will identify are not professional ones but rather «ideological» ones. These roles were not a given, at least not in the sense of the typical roles of a scientist mentioned above. Carbonell actively cut them out for himself. In this process he was able to transform himself from an «outsider» into a highly visible figure in the public sphere. We will see in how far he may be described as a «celebrity scientist» ${ }^{4}$. On the one hand he constantly tries to instrumentalize the media for his scientific but also his socio-political goals. Yet on the other hand the media seem to impose their own logic on his persona. I will argue that the way he is framed in public even turns him into a commodity. The case of Carbonell will therefore also serve as an instructive example of what has been called the «medialization» of science ${ }^{5}$.

\section{The young archaeologist}

Eudald Carbonell was born in the village of Ribes de Freser in Northern Catalonia in 1953. In 1991, he became an assistant professor at the Universitat Rovira $i$ Virgili and since 1999 holds the chair for prehistory at this university in Southern Catalonia (mainly located in the city of Tarragona). He is also the director of the Institut Català de Paleoecologia Humana i Evolució Social (IPHES). However, for the first twenty years of his scientific career, the 1970s and the 1980s, it was by no means certain that Carbonell would achieve such a prominent academic position.

In 1972, Josep Canal (b. 1920) was among the founding members of the Associació Arqueologica de Girona (AAG). Canal was not a professional archaeologist by training but an economist. Yet he was able to galvanize interest in Catalan archaeology, in particular for the prehistoric period. One may interpret the activities of the AAG as an attempt to create a protected

4. Fahy, Declan. The celebrity scientists: A collective case study. Dublin: Dublin City University; 2010.

5. This term has been coined among others by Peter Weingart. For an authoritative synthesis of the emergence and effects of this science-media-coupling see Rödder, Simone; Franzen, Martina; Weingart, Peter, eds. The sciences' media connection - communication to the public and its repercussions. Dordrecht: Springer; 2012. 
social space in the last years of Francoism for its members to assert their own identity. Top of their agenda was to determine since when Catalonia had been inhabited and whether there had been a Lower Paleolithic in the Northeast of the peninsula ${ }^{6}$. Clearly, identity politics has different levels and in the 1970s, Canal and his fellow members from the AAG mostly used the terms «Girona» or the «comarques gironines» (referring to the Northern part of Catalonia) more often than «Catalonia» or «Catalan» 7 .

Canal soon became an important mentor for the young archaeologist ${ }^{8}$. Carbonell's personal research agenda or one might even say his «mission» to find evidence for the earliest human settlement in Catalonia and later in Spain can be traced right back to the beginning of his career in the mid-1970s. It needs to be situated in this specific Catalan context of searching for one's own historic roots in a community that was only about to professionalize itself. When I interviewed Carbonell in March 2010, he told me that he participated in his first excavation in 1973 and gave his first academic paper in 1974, when he was barely twenty years old.

In these years Canal, Carbonell and other members of the AAG were excavating open-air fluvial terraces of the river Ter in the region of Girona. In the summer of 1974, Carbonell literally went out of the door of his home in Ribes de Freser to look for stone tools nearby. This led to his first scholarly publication in 1976 where he and his co-authors proudly claimed to have proven the existence of a Lower Paleolithic in Catalonia9.

An important actor in the network of the AAG was the French paleoanthropologist Henry de Lumley (b. 1934). His contacts with Catalan researchers date back to the early 1960s. Together with Eduard Ripoll (1923-2006), a prehistorian at the Universitat Autònoma de Barcelona, de Lumley had already excavated the Neanderthal site of Abric Romaní (Middle Paleolithic) in Capellades ${ }^{10}$. Subsequently, from 1964 onwards de

\footnotetext{
6. The Lower Paleolithic is defined as the period in which stone tools were used for the first time. Therefore the exact time span differs from region to region.

7. Canal, Josep; Soler, Narcís. El Paleolític a les comarques gironines. Girona: Caixa d'Estalvis Provincial; 1976.

8. Carbonell, Eudald; Bellmunt, Cinta S. Els somnis de l'evolució. Barcelona: La Magrana; 2003, p. 79.

9. Carbonell, Eudald; Culí, Núria; Busquets, Ramon. El Paleolític inferior i mitja a la conca del Freser. Cypsela. 1976; 1: 23-27; Carbonell; Bellmunt, n. 8, p. 77.

10. Ripoll, Eduard; Lumley, Henry de. Le remplissage et l'industrie Moustérienne de l'abri Romaní. L'Anthropologie. 1962; 66 (1-2): 1-35. Ripoll, Eduard; Lumley, Henry de. El Paleolítico medio en Cataluña. Ampurias. 1964-1965; 26-27: 1-70.
} 
Lumley made a name for himself with his discoveries of hominid fossils in the Arago cave near Tautavel, today dated at about 450,000 years ${ }^{11}$. The site is in Roussillon in France just across the border from Spain. In 1971, de Lumley had mentioned - very briefly - «une importante industrie paléolitique» at Puig d'en Roca ${ }^{12}$. Already in 1972, Canal followed this lead when he started to excavate the site near Girona ${ }^{13}$. Later Carbonell joined him and they claimed to have found numerous stone tools from the Lower Paleolithic ${ }^{14}$. In 1973, Josep Canal contacted de Lumley personally to point him to the excavations the AAG carried out in Northern Catalonia. In his letter to de Lumley, Canal stresses the lack of scholars able to decipher and date the complicated stratigraphy ${ }^{15}$.

The common interest of the AAG and de Lumley was to provide evidence for an early habitation of the region of Roussillon-Catalonia. Obviously their discoveries would re-enforce each other. It was a «win-win-situation» ${ }^{16}$. Their collaboration may be called a «deal». In return for access to promising sites in Catalonia, de Lumley would provide his expertise and his growing international reputation and the network that came with it. And in 1976 the French paleoanthropologist had something very special to offer.

\section{The exhibition on Catalonian prehistory in $\mathbf{1 9 7 6}$}

In mid-September 1976, the Ninth Congress of the International Union of Prehistoric and Protohistoric Sciences (IUPPS) took place in Nice in Southern France. The secretary of the gathering was Henry de Lumley. As is custom

11. For a recent overview and contextualization of the discoveries see Lumley, Henry de. La Grande Histoire des premiers hommes européens. Paris: Odile Jacob; 2007, p. 171-198.

12. Lumley, Henry de. Le Paléolitique inferieur et moyen du midi Méditerranéen dans son cadre géologique. Vol 2. Paris: CNRS; 1971, p. 330, also see figure on p. 321.

13. Canal; Soler, n. 7, p. 23; Abad, Joan et al. Humans! Els primers pobladors de Catalunya. Barcelona: Fundació «La Caixa»; 2000, p. 11; Carbonell; Bellmunt, n. 8, p. 79.

14. Canal, Josep; Carbonell Eudald. Les estacions prehistòriques del Puig d'en Roca (Girona). Girona: Associació Arqueològica; 1979. For the «history» of site see Carbonell, Eudald; Pons, Enriqueta. Girona abans de Girona. Prehistòria. Girona: Ajuntament de Girona; 1987, p. 16-17 and Terradas, Xavier. La prehistòria. In: Alberch, Xavier; Burch, Josep, eds. Història del Gironès. Vol. III. Història de les comarques gironines. Girona: Diputació de Girona; 2002, p. 23-127 (43-48).

15. Letter J. Canal to H. de Lumley, 24 Mar 1973, reprinted in Carbonell, Eudald et al. El complex del Plistocè mitjà del Puig d'en Roca. Madrid: CSIC; 1988, p. 135.

16. Canal; Carbonell, n. 14, p. 2. 
with this kind of congress, several excursions to archaeological sites were scheduled. Already in 1973, de Lumley had contacted the archaeologist Lluís Pericot (1899-1978) from the Universitat de Barcelona to include a site from Northern Catalonia in the program, suggesting Empúries ${ }^{17}$. The prospect of receiving a substantial number of prehistorians from all over the world gave rise to the idea to present the recent discoveries to the international community. In fact, the AAG mounted the twin exhibitions «El Paleolític a les comarques gironines» ${ }^{18}$. One part was shown in Girona in the medieval Fontana d'Or building and the other one in the archaeological museum in Banyoles. Canal and the young prehistorian Narcís Soler edited the accompanying publication. For Carbonell this brought the opportunity to present the tools found at Puig d'en Roca ${ }^{19}$.

The twin exhibitions opened on 30 September 1976. The headline in La Vanguardia Española was precisely the «message» the AAG wanted to convey to the general public: «The existence of man in Catalonia dates back to the Lower Paleolithic». Foreign scientists from «22 countries» - as the newspaper proudly remarked - were invited to applaud and thereby bestow international respectability on the exhibition and the research that had led to it ${ }^{20}$. The visitors from abroad not only visited Empúries (a Greek colony, i.e. an excavation of classical antiquity) but also some of the recently discovered Palaeolithic sites ${ }^{21}$.

In mounting the exhibition, the AAG was able to rely on the support of museums, associations and in particular, local political bodies as well as financial support from the Caja de Ahorros Provincial, a local bank. The Servei d'Investigacions Arqueologiques of the Diputació Provincial de Girona (the Provincial Office of the Province of Girona) acted as co-organizer of the exhibitions. The president of the Comité de Honor was no one else but the Spanish Queen Sofía herself ${ }^{22}$.

17. Letter H. de Lumley to L. Pericot, 27 Sep 1973, Fons Pericot. Correspondència / Congrès Int. des Sciences Préhistoriques et Protohistoriques (IXe: Niça, 1976), Secció de Manuscrits, Biblioteca de Catalunya, Barcelona.

18. Canal; Soler, n. 7, p. 9.

19. Canal; Soler, n. 7.

20. Vila, J. Gerona: La existencia del hombre en Cataluña remonta al paleolítico inferior. La Vanguardia Española. 6 Nov 1976: 44; Carbonell; Pons, n. 14, p. 17, Canal, Josep; Carbonell, Eudald. Catalunya Paleolítica. Barcelona: Generalitat de Catalunya; 1989, p. 5.

21. La Vanguardia Española. 22 Sep 1976: 32.

22. Europa Press. La reina doña Sofía presidenta de honor de dos exposiciones sobre la prehistoria gerundense. La Vanguardia Española. 23 Sep 1976: 38. 
At the exhibition in Girona, music from Pink Floyd's famous record Dark side of the moon was played ${ }^{23}$. This may seem like a quaint detail yet it also indicates that the exhibition aspired to be «modern» or even to form part of a counter-culture. According to Carbonell and Canal, the huge success of the exhibition in Girona - that is the comparatively large number of 15,000 visitors - motivated Eduard Ripoll (at the time director of the Museu Arqueologic de Barcelona) to transfer the exhibition at least in parts to Barcelona ${ }^{24}$. Here it was shown between December 1976 and January 1977 in the Biblioteca de Catalunya. The slim catalogue authored by Carbonell himself conveys an idea of what was displayed in the glass cabinets. The objects representing the Paleolithic were all stone tools, a substantial part of them from Puig d'en Roca ${ }^{25}$.

The «timing» of the exhibitions on Catalan prehistory in Girona and Banyoles barely a year after Franco's death in November 1975 is striking. The broad institutional support from the political authorities in Girona may be interpreted as an attempt of Catalan identity politics in the midst of a major political transition. Antoni Xuclà i Bas, at the time president of the Diputació Provincial de Girona, emphasized how these investigations would facilitate «a better understanding of the simple beginnings of our past that will help us to understand the present ${ }^{26}$. At the same time it is important to stress the continuities between the late dictatorship and the early democracy. The investigations of the AAG, the formation of a network of Catalan archaeologists and the contact established with French researchers such as Henry de Lumley date back to the 1960s and early 1970s.

\footnotetext{
23. Carbonell; Bellmunt, n. 8, p. 81.

24. Carbonell, Eudald; Canal Josep. El Paleolític inferior a les comarques gironines: el començament. In: Alberch, Xavier; Burch, Josep, eds. Història del Gironès. Vol. III, Història de les comarques gironines. Girona: Diputació de Girona; 2002, 48-50 (49-50); Carbonell; Bellmunt, n. 8, p. 81.

25. Carbonell, Eudald. Exposició: Materials paleolítics de les comarques gironines. Biblioteca de Catalunya, Desembre 1976-Gener 1977. S.I.; n.d. [1976], p. 14-20.

26. Canal; Soler, n. 7, p. 7. One may suspect that the situation in other Spanish regions (what would soon become the Autonomous Communities) was somehow similar to the one in Girona respectively Catalonia. In the transición, politicians expected archaeologists (and other historical disciplines) to provide a narrative of «roots». Yet clearly more research is needed to assess this.
} 


\section{Fighter against the «establishment»}

So far we have based our narrative on Carbonell's early career primarily on contemporary sources from the 1970s. The picture that emerges includes the following features: the research of the AAG, as well as their efforts to popularize their findings could count on very broad support, and their claims were favorably received. Local and regional institutions and authorities, the Catalan media as well as renowned prehistorians from abroad applauded their results.

This narrative changes significantly if we look at later sources in particular from the turn of the millennium onwards. Here Carbonell, Canal and their fellow members from the AAG claim that they received little scientific recognition at the time. Carbonell even speaks of a «very hostile environment» and that nobody would believe in the discoveries made in the Vall del Freser ${ }^{27}$. In 2002, Carbonell and Canal maintained that they had to pursue their research «practically at the margin of the official institutions». Allegedly it had been extremely difficult to convince the «authorities» that the stones that had been found were actually man-made tools and not shaped by the elements ${ }^{28}$.

They argue that at the time the general opinion was that there had been no Lower Paleolithic in Catalonia. Between 1973 and 1976, the AAG «informed the academic authorities about the results of the research. Yet because of their indifference, there was no other way but to look for acknowledgement in other spheres» ${ }^{29}$. In other words, the AAG had to go public and mount the twin exhibitions on Catalan prehistory in the autumn of 1976. According to this account, it was the approval of the prehistorians from the IUSPP Congress in Nice who had come to Girona that settled the «debate» and silenced the «critics» ${ }^{30}$. It comes as no surprise that Henry de Lumley is credited with a central role in this narrative. Unlike the «authorities» in Spain, he did believe in an early inhabitation of Catalonia, citing Puig d'en Roca as an example ${ }^{31}$.

\footnotetext{
27. Carbonell; Bellmunt, n. 8, p. 77.

28. Carbonell; Canal, n. 24, p. 50.

29. Abad et al., n. 13, p. 19. Very similar the Catalan Wikipedia-entry on Carbonell: ca.wikipedia. org/wiki/Eudald_Carbonell_i_Roura (cited 11 Feb 2013).

30. Abad et al., n. 13, p. 19.

31. Carbonell; Canal, 2002 n. 19, p. 49; Carbonell; Bellmunt, n. 8, p. 79-80; Abad et al., n. 13, p. 19, also see p. 11. Francesc, Solà. Josep Canal. Arqueólogo; representante de la Associació d'Arqueologia de Girona. La Vanguardia (Vivir en Girona). 13 Dec 2000: 2.
} 
However doubts or criticism as regards the findings of the AAG are absent from the sources of the 1970s. There is at least no evidence in print to support the picture of Canal and his fellow members of the AAG, including the young Carbonell, as underdogs fighting a dogmatic academic establishment. In fact, archaeology and in particular prehistoric archaeology were barely institutionalized in (Northern) Catalonia at the time. It is no coincidence that the AAG emerged on a private initiative and was at least not formally linked to any academic institution. Until 1991 Girona had no university, only some smaller units of tertiary education. This included for example the Col-legi Universitari de Girona which formed part of the Universitat Autònoma de Barcelona. And it is in this institutional context that Carbonell pursued his undergraduate studies in the 1970s.

When Canal and Carbonell speak of the «official science», they might have had Miquel Tarradell's (1920-1995) Les arrels de Catalunya (The roots of Catalonia) in mind. In this classic work on Catalonian prehistory from 1962, Tarradell did indeed state the absence of a Lower Paleolithic in Catalonia. Yet he did so in a non-dogmatic and cautious way: absence of evidence is no evidence of absence. In other words: none of the stone tools that had been found so far suggest a very early population of what is today Catalonia. And Tarradell explicitly stated that his claim might be falsified by new discoveries ${ }^{32}$. The other eminent Catalan (prehistoric) archaeologist of the time was Lluís Pericot who we mentioned already. Yet he actually defended the interpretation of the AAG that the stone tools in question were handmade, as Carbonell acknowledges himself ${ }^{33}$. In his autobiography of 2003, Carbonell explicitly mentions three «skeptics» who denied (at first) the existence of a Lower Paleolithic in Catalonia: Eduard Ripoll, Josep Fernández de Villalta and Joan Maluquer de Motes ${ }^{34}$.

Ripoll had a chair at the Universitat Autonoma de Barcelona and was an expert on prehistoric art. He had been Carbonell's supervisor for his tesina (MA thesis): As mentioned above, it was Ripoll who brought the Girona exhibition of the AAG to Barcelona, hence his «resistance» was at

32. Tarradell, Miquel. Les arrels de Catalunya. Barcelona: Vicens Vives; 1962, p. 5; compare Soler, Narcís. El paleolític de Catalunya, entre les arrels i el segle XXI. Cota Zero. 2003; 18: 18-33 (18-19).

33. Carbonell; Pons, n. 14, p. 17.

34. Carbonell; Bellmunt, n. 8, p. 80. 
most temporary ${ }^{35}$. Villalta was a paleontologist at the «Jaume Almera», the Institute for Earth Sciences of the CSIC in Barcelona. At least in public, Villalta never spoke out against the claims of the AAG. Maluquer de Motes held a chair for prehistory at the Universitat de Barcelona. In his research he focused on the Iron Age. He may have doubted the anthropogenic character of the stones in question. Yet if so, this would have been rather in a half provocative, half joking manner as he himself was no expert in this particular field of lithic technology $y^{36}$.

Therefore we may assume at most that there may have been an informal (and transient) critique of the claims of the AAG by some - certainly not all-Catalan archaeologists with academic positions. Yet that hardly amounts to massive and hostile resistance. What emerges in the later writings of Carbonell, Canal and in other sources is a heroic story of Catalan archaeologists -i.e. themselves - short of resources but full of commitment and determination, in which they ultimately prevail. The allusion to «disinterest» and «hostility» from the «official science» and the «institutions», appears to be to a large degree a later construct that serves to underline their own achievement.

Today it is beyond doubt that there was a Lower Paleolithic in Catalonia. Already in 1989, Canal and Carbonell proudly presented Catalunya paleolitica, where they summarize the research of the AAG of the previous two decades. The actual support of the Catalan political authorities for their research is shown once again in this nicely illustrated volume of more than 400 pages. 24 years after the first exhibition on Catalan prehistory, in November 2000, an exhibition in Girona called Humans. Els primers pobladors de Catalunya was inaugurated. The excavation site of Puig d'en Roca was prominently featured with a reconstruction. The accompanying catalogue made ample reference to the heroic story line we have sketched ${ }^{37}$. In this reconstruction of the history of the 1970s, all references to «Girona» or «Gironese» were «upgraded» to «Catalan». The media picked up on this narrative of hardship and ultimate vindication. El País for instance wrote:

35. At least from 1976 onwards, Ripoll clearly supported the claims of the AAG. Lumley, Henry de; Ripoll, Eduard. Las investigaciones del Paleolítico Inferior y Medio de los últimos años y sus resultados. In: Canal; Soler, n. 7, 9-11.

36. I am indebted to Narcís Soler and Assumpció Vila for their generosity in sharing their knowledge of these «skeptics» with me.

37. Abad et al., n. 13, p. 6-19. 
«The exhibition also intends to pay homage to the Catalan archaeologists and paleontologists. They made important contributions and investigated in extremely difficult conditions» ${ }^{38}$.

\section{Hunter of the «First European»}

A crucial international context for the research into the Lower Paleolithic in Catalonia in the 1970s, is the search for the oldest human traces in Europe. At the IUSPP congress in 1976, the Czech prehistorian Karel Valoch boldly asserted that hominid presence in Europe went back 1.5 million years. Yet the oldest fossil known at the time, the mandible found in Mauer near Heidelberg in 1907 (Homo heidelbergensis), was «only» about 500,000 years old. With hindsight, Eudald Carbonell considers Valoch's contention as the opening fanfare for the ensuing hunt in which he wanted to participate ${ }^{39}$. In the autumn of 1976, only a month after the opening of the exhibition in Girona, Carbonell attended an international congress on prehistory in Morella (Castellón). There «the arrival of the first hominids in Europe was much discussed», Carbonell recalls ${ }^{40}$.

A major actor in this «hunt» was Henry de Lumley. His support for the AAG in the 1970s also brought him into touch with Carbonell. It was the beginning of a long-lasting friendship as Carbonell told me. "I love him as if he were my brother and my father» ${ }^{41}$. Ideological differences -Carbonell considers himself a communist while de Lumley is politically a conservative - did not hamper their collaboration. In 1981, Carbonell went to Paris to do his PhD in Quaternary geology with de Lumley at the Université Pierre et Marie Curie. In 1986, he received his degree. Already in 1981, de Lumley organized an exhibition at the Musée de l'Homme in Paris with the programmatic title: Les premiers habitants de l'Europe. 1500000-

38. Bagué, Gerar. «Humans!» muestra la vida de los homínidos en lo que hoy es Cataluña. El País. 23. Nov 2000. La Vanguardia also described the exhibition as an «homage» to researchers such as Canal. Solà, n. 31.

39. Carbonell; Bellmunt, n. 8, p. 83; Canal; Carbonell, n. 14, p. 7.

40. Carbonell, Eudald; Bermúdez de Castro, José María. Atapuerca. Perdidos en la colina. La historia humana y científica del equipo investigador. Barcelona: Destino; 2004, p. 58-59, quote p. 59.

41. Interview author with Eudald Carbonell, 10 Mar 2010, Tarragona. 
100000 ans. He put Carbonell in charge of the section on lithic industry ${ }^{42}$. De Lumley also edited the academic publication that accompanied the exhibition. It assembled contributions from dozens of researchers from all parts of Europe including Carbonell. They all seemed to agree that Europe was indeed populated already 1.5 million years ago ${ }^{43}$.

In the summer of 1982, Josep Gibert and his team found - what he believed to be- part of a hominid skullcap at the site of Venta Micena near Granada («Orce Man»). The Catalan paleontologist thought the fossil might be well over one million years old ${ }^{44}$. By then Carbonell had long joined the hunt himself and had ventured outside Catalonia. Already in 1981, he - jointly with five other Catalan prehistorians - had published an article on the Cueva Victoria, a site in Murcia. They purported to have found the oldest place of human occupation in the Iberian Peninsula. Three stone tools as well as animal bones that might have been used as tools was all the evidence they put forward to sustain their audacious claim ${ }^{45}$. In 1983, in an article directed at a more general audience, Carbonell and the archaeologist Jordi Estévez stated confidently, that «1.2 million years ago the entire south of Europe was already inhabited, and therefore also the Catalan lands» ${ }^{46}$.

By the mid-1990s, with finds of hominid fossils in Dmanisi (Georgia) and Boxgrove (England), there were even more contenders for the title of the oldest European. Yet this increasing number of claims did not please everybody, in fact it led to a counter-reaction. In 1994, Wil Roebroeks and Thijs van Kolfschoten critically reviewed these publications and questioned the chronological framework of their field. The two Dutch archaeologists identified a clear watershed and drew the line between «contested» and «uncontested» evidence of human presence at half a million years. They put forward a «short chronology», according to which Europe had not been

42. Carbonell, Eudald. L'Institut de Paléontologie Humaine. Lorsque j'était un jeune étudiant. In: Lumley, Henry de; Hurel, Arnaud, eds. Cent ans de préhistoire. L'Institut de Paléontologie Humaine. Paris: CNRS; 2011, p. 231-234 (232).

43. Lumley, Henry de, ed. Les premiers habitants de l'Europe. 1500000-100000 ans. 2nd ed. Paris: Laboratoire de Préhistoire du Musée de l'Homme; 1982. See p. 18-19 for a map and information on the Catalonian fluvial terraces from the Paleolithic.

44. See Carandell's article in this volume.

45. Carbonell, Eudald; Estévez, Jordi; Moyà-Solà, Salvador; Pons Moyà, Joan; Agustí, Jordi; Villalta, Josep F. de. Cueva Victoria (Murcia, España). Lugar de ocupación humana más antiguo de la Peninsula Ibérica. Endins. 1981; 8: 47-57.

46. Carbonell, Eudald; Estévez, Jordi. Les primeres occupacions humanes en els Països Catalans. Avenç. 1983; 57: 67-70 (68). 
populated before roughly 500,000 years ago. Roebroeks and van Kolfschoten analyzed a large number of «artifacts» from 62 sites. They maintained that many of these alleged hand-axes, choppers and flakes might not have been manmade at all. Instead natural processes such as erosion and weathering had shaped the stones. And while there are around 20 sites with hominid fossils all over Europe of the «Mauer» age or slightly younger, «we do not have a single (uncontested!) tooth yet» that is older than 500,000 years ${ }^{47}$. Roebroeks and van Kolfschoten more or less explicitly stated that their colleagues had not been critical enough with their findings. This did not go down well with Carbonell.

\section{An advocate for Spanish science}

At the aforementioned conference in Morella in October 1976, Carbonell made the acquaintance of Emiliano Aguirre, at the time one of the leading Spanish paleoanthropologists ${ }^{48}$. And two years later Carbonell started his first excavation season in the Sierra de Atapuerca near Burgos, when the project directed by Aguirre started. Carbonell continued to work at other sites as well, not least in Catalonia itself. For example in the same year 1978, he started to investigate the Mesolithic site of Sota Palou ${ }^{49}$. Since 1983 he has also been in charge of the excavations at Abric Romaní ${ }^{50}$.

Yet it seems fair to say that his participation in the Atapuerca project was decisive for his professional success. In 1991, Aguirre retired and Eudald Carbonell became one of the three co-directors of the EIA (Equipo de Investigación de Atapuerca) along with the two paleoanthropologists Juan Luis Arsuaga and José María Bermúdez de Castro. In 1994, the team unearthed fossils which would soon turn out to be more than 800,000 years

47. Roebroeks, Wil; Kolfschoten, Thijs van. The earliest occupation of Europe - a short chronology. Antiquity. 1994; 68 (260): 489-503, quote p. 500.

48. Carbonell; Bellmunt, n. 8, p. 139.

49. Carbonell, Eudald et al. Sota Palou. Campdevànol. Un centre d'intervenció prehistòrica postglaciar a l'aire lliure. Girona: Diputació de Girona; 1985.

50. There are numerous articles, e.g.: Vallverdu, J., et al. Short human occupations in the Middle Palaeolithic level i of the Abric Romaní rock-shelter (Capellades, Barcelona, Spain). Journal of Human Evolution. 2005; 48 (2): 157-174; and most recently the volume Carbonell, Eudald, ed. High resolution archaeology and Neanderthal behavior: Time and space in level J of Abric Romaní (Capellades, Spain). Dordrecht: Springer; 2012. 
old and hence were hailed as the oldest in Europe. In the following years Carbonell hardly missed an opportunity to point out that they had falsified the «paradigm» of the short chronology of Roebroek and van Kolfschoten ${ }^{51}$.

That these discoveries marked a turning point in Carbonell's career can also be neatly illustrated by browsing through his publication record ${ }^{52}$. There are numerous publications dealing with his excavations in Catalonia which appeared between the mid-1970s and the late 1980s. Yet most of them are written in Catalan, i.e. were of limited impact. Many of these texts are reports and summaries of excavations rather than research articles in peer-reviewed international journals. Carbonell hardly published anything at all in English until $1992^{53}$. Yet with his new position as a co-director and with the flush of hominid fossils coming to light in Atapuerca from the early 1990s, Carbonell was able to publish a host of articles in international journals with a high impact factor.

Becoming a co-director of a research project with growing prestige «somehow» turned the Catalan archaeologist Carbonell into an advocate of Spanish science. In what follows, I will try to elucidate this «somehow». In 1997, the EIA named a new hominid species Homo antecessor, the «oldest European». The Spanish media gave this publication in Science a national spin. Very much in tune with the comments from his fellow researchers, Carbonell boasted: «Atapuerca has become the most important excavation site in the world ${ }^{54}$. And more than a decade later he proudly remembered in his blog: «For the first time a Spanish team has named a human species» ${ }^{55}$. Carbonell even claimed that the discoveries of the EIA constituted the most

51. Bosch, Rosa M.; Corbella, Josep. A partir de ahora van a contar con nosotros. La Vanguardia. 30 May 1997: 25; Corbella, Josep; Carbonell, Eudald; Moyà-Solà, Salvador; Sala; Robert. Sapiens: el llarg camí dels homínids cap a la intel.ligència. Barcelona: Edicions 62; 2000, p. 83-84; Carbonell, Eudald; Sala, Robert. Planeta humano. Barcelona: Ediciones Península; 2000, p. 111; Carbonell; Bermúdez de Castro, n. 40, p. 304.

52. See the list assembled: webgrec.urv.es/cgi-bin/DADREC/crfitgrup.cgi?FONT=3\&IDI $=$ CAT\&PID $=39001 \&$ PAR $=$ AUTOQUAT (cited 11 Feb 2013).

53. There was only one article in 1987 with Aguirre as first author and Carbonell as one of 14 co-authors: Aguirre, Emiliano et al. Middle Pleistocene human occupations in the Sierra de Atapuerca (Ibeas, Burgos, Spain). L'Anthropologie. 1987; 91 (1): 29-44.

54. Bosch; Corbella, n. 51.

55. Carbonell, Eudald. La reconstrucción completa y en 3D del cráneo del «Homo antecessor». 2008; www.elmundo.es/elmundo/2008/11/21/sapiens/1227256678.html (cited 11 Feb 2013). 


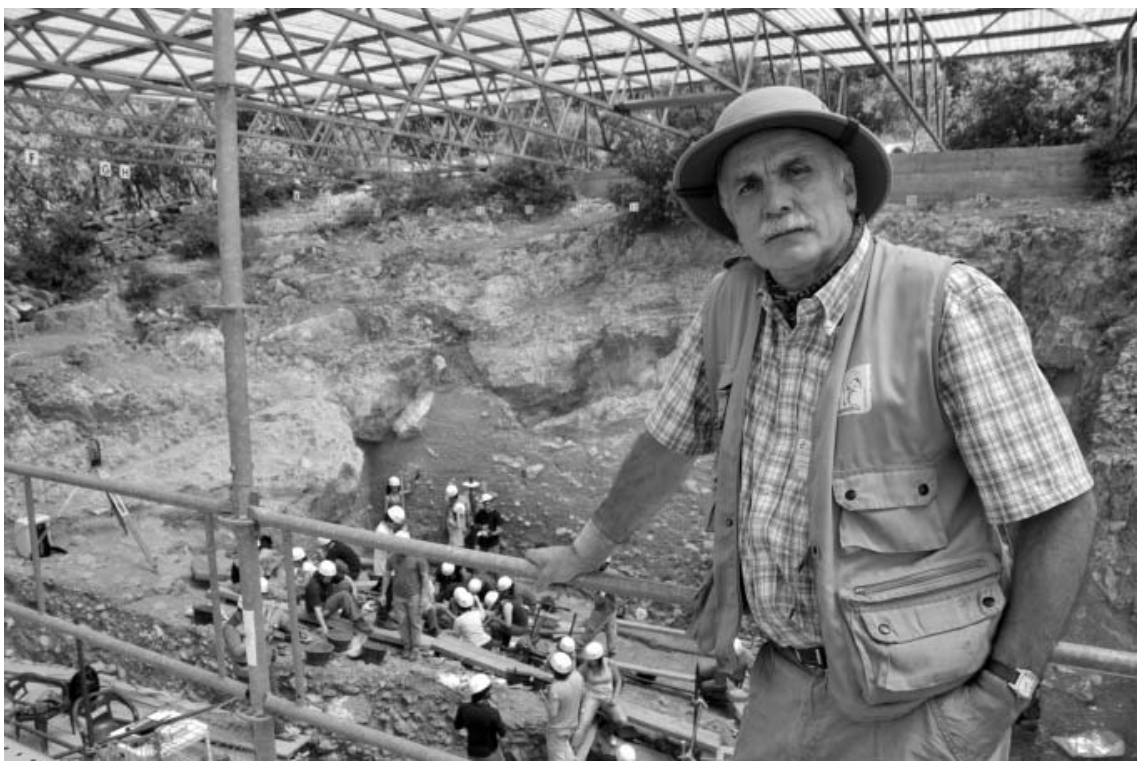

Figure 2. In his role as co-director of the Atapuerca project Carbonell stages himself as a champion of Spanish science. Source: IPHES/Jordi Mestre.

important contribution of Spanish science since the physiological work of Santiago Ramón y Cajal (Nobel Prize in 1906) ${ }^{56}$.

Due to the naming of Homo antecessor in 1997, the EIA was awarded the prestigious Premio Principe de Asturias in the autumn of that year. Honored by the award, Carbonell was proud to tell the press that « 98 percent of the work had been done by specialists from this country. There are geologists, paleontologists, anthropologists, archaeologists (...) we have created a real school of Quaternary research» ${ }^{57}$. And he told me: «The fossils are ours, we work on them ${ }^{58}$. The EIA pursues a distinctly national research strategy: «Spanish» fossils belong to the Spanish.

56. Aguirre, Emiliano; Carbonell, Eudald; Bermúdez de Castro, José María; Arsuaga, Juan Luis. Atapuerca: 25 años que cambiaron la historia. Burgos: Diario de Burgos; 2002, p. 66.

57. Madridejos, Antonio; P.Z. Un burgalés de 800.000 años. El Periódico. 3 May 1997: 19.

58. Carbonell, n. 41. 


\section{Fighter against «scientific colonialism»}

In order to understand Carbonell's nationalist stance, it is necessary to introduce the concept of «scientific colonialism». Most Spanish prehistoric archaeologists would agree that they had been dominated and even exploited by a powerful French academic establishment since the late nineteenth century. Later on British, US-American and German scholars joined the «French colonialists» ${ }^{59}$. The foundation myth of this alleged scientific colonialism is Émile Cartailhac's denial of the authenticity of the cave paintings of Altamira (discovered in 1878/9). Yet according to Oscar Moro, most of the «histories» of Altamira «have been largely hagiographical, acritical and anecdotal». He argues that this narrative of Spanish researchers as underdogs and malevolent French scholars has been instrumentalized in order to create a «symbolic site», a «national Spanish monument». Moro shows that «the French resistance in accepting the high antiquity of the paintings» was exaggerated, and that there is no historical basis for the polarization of two opposing camps, a Spanish and a French one ${ }^{60}$.

Yet this is exactly what turned into the myth of Altamira, a narrative undergirded by the idea of «scientific colonialism». This narrative was mobilized time and again in the context of other excavations in Spain in the course of the twentieth century. The allegation of scientific colonialism was used as a rhetorical resource to plead for funding and support for research but even more so to give cohesion to the emerging disciplines dealing with prehistory and hence it played an important part in their professionalization and institutionalization ${ }^{61}$.

It still does: When I addressed the issue of scientific colonialism, Carbonell responded: «The first (prehistoric) cave that was discovered was Altamira and the French said that it was not - until they discovered Lascaux and then

59. Díaz-Andreu, Margarita. Historia de la arqueología en España. Estudios. Madrid: Ediciones Clásicas; 2002, p. 103-117.

60. Moro, Oscar. Art caves as symbolic spaces. The case of Altamira. In: Maríková-Kubková, Jana; Schlanger; Nathan; Lévin, Sonia, eds. Castrum Pragense. Sites of memory between scientific research and collective representations. Prague: Archeolosgicky ústav Akademie ved Ceske republiky; 2009, 69-78 (69-71).

61. Lanzarote, José María. A «science of exportation»? International scholarship in the professionalization of prehistory in Spain (1902-1922). In: Roca, Antoni, ed. Proceedings of the 4th International Conference of the ESHS, Barcelona, 18-20 Nov 2010. Barcelona: SCHCT-IEC; 2012, 1110-1115. 
they said that Altamira also was prehistoric». He spoke of the longue durée of French dominance and «chauvinism» in Spanish prehistory ${ }^{62}$.

As mentioned earlier, still in the 1970s the Catalan researchers very much depended on support from their French colleagues. Henry de Lumley (and his wife Marie-Antoinette de Lumley, a renowned paleoanthropologist) continued to play a somehow ambiguous role in Spanish human origins research $^{63}$. De Lumley provided his expertise (dating techniques, for example) but also his international network in order to ascertain the existence of a Lower Paleolithic in Catalonia. He offered opportunities to publish, to participate in congresses and in exhibitions and he trained Spanish scholars such as Carbonell. At the same time he tried to reap maximum benefit from his access to promising sites in Spain. When the first important hominid fossils including two fragments of a hominid mandible (AT-75 and AT-83) were found in the Sima de los Huesos in Atapuerca in 1984, de Lumley suggested to Aguirre to hand them over to him, arguing that the fossils should be investigated in Paris ${ }^{64}$. Aguirre declined this offer not least because his young disciples, among them Carbonell, pressured him to investigate the fossils themselves. In the narrative of the EIA this refusal marked a turning point. In Carbonell's view, Atapuerca is clearly a national project. «We did that precisely to avoid colonialism (...) I think our generation was the first generation to get rid of this» ${ }^{65}$.

\section{Communist and «agent of reflection»}

Carbonell would like his scientific activities to be understood as political. In his autobiography of 2003, each chapter follows the same pattern: He starts off with the general political context of the time, be it the Vietnam War or the fall of the Berlin Wall. Then he describes new developments

62. Carbonell, n. 41. In fact, the cave of Lascaux was only discovered in 1940. Yet examples of prehistoric art in the Dordogne such as Font-de-Gaume and Les Combarelles were already discovered in 1901. Similar in Carbonell; Bermúdez de Castro, n. 40, p. 59.

63. For the role of both de Lumleys in initiating the debate about the «Orce man», see Carandell, this dossier, for their ambiguous role in the Atapuerca Project, see below and in more detail Hochadel, Oliver. El mito de Atapuerca. Orígenes, ciencia, divulgación. Bellaterra: Edicions UAB; 2013, p. 63-67, 79, 80, 83, 126, 174, 176, 185

64. Carbonell; Bermúdez de Castro, n. 40, p. 172-173.

65. Carbonell, n. 41. 
in human origins research before detailing his own investigation. In 1976, Carbonell joined the PSUC, the Catalan branch of the Spanish Communist Party. In this phase of the transición, he even decided to dedicate «80\%» of his time to politics ${ }^{66}$. When I interviewed him in his office in Tarragona, I noticed a bust of Lenin and some kind of red flag with a hammer and sickle. Yet he has not been active in any political party for some time. He pursues his socio-political agenda in a different way.
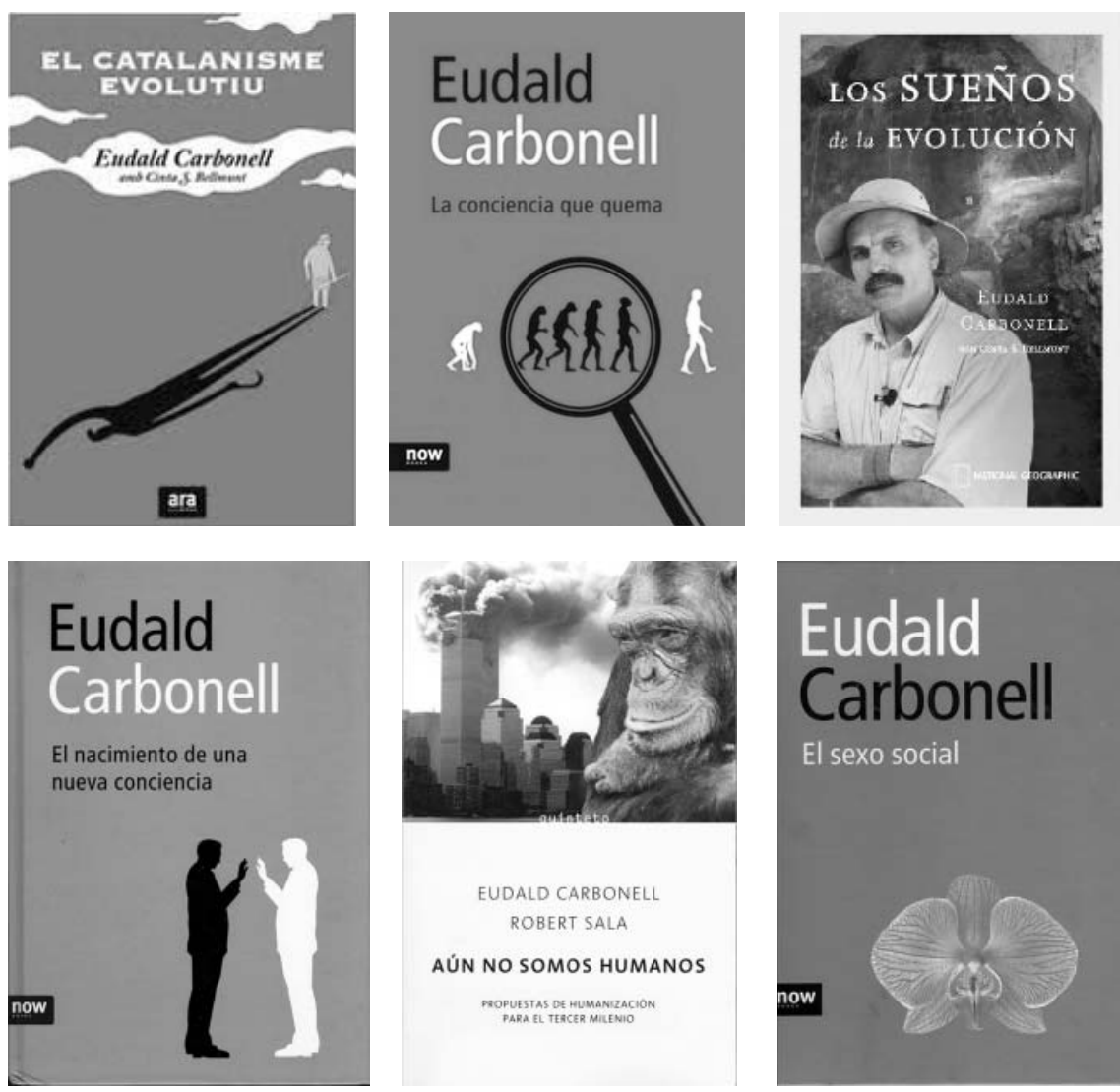

EUDALD CARBONELL

ROBERT SALA

AÚN NO SOMOS HUMANOS

MOPUESTAS DE HUMANEZACION para EL. TERCER MiLENIO

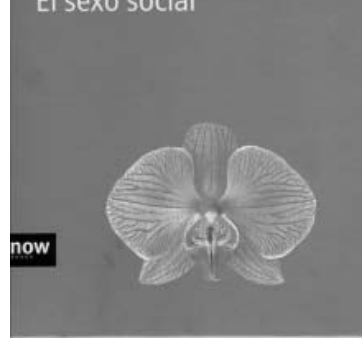

Figure 3. In his books addressed to the general public Carbonell pursues his political agenda of socializing knowledge.

66. Carbonell; Bellmunt, n. 8, p. 82-83; compare Carbonell, Eudald; Bellmunt, Cinta S. Catalanisme evolutiu. Barcelona: Ara Llibres; 2011, p. 47. 
Since the late 1990s, Carbonell has become a prolific author of half a dozen books, directed at the general public ${ }^{67}$. Atapuerca or any of his other excavation projects are barely ever mentioned. Carbonell conceives of himself «very much as an agent of reflection». He would like to have his scientific publications distinguished from his popular writings: «These books are essays, they have nothing to do with science ${ }^{68}$.

Backed by his scientific credentials, Carbonell addresses a variety of political, philosophical and social issues. While the biological process of «hominization» is complete, the cultural process of «humanization» has still not been accomplished. To this end, it is necessary to «socialize» knowledge. Archaeology and science in general are for Carbonell instruments for overcoming social hierarchies and inequalities. This also includes the overcoming of gender inequalities with the help of new technologies. Carbonell mentions extra-uterine pregnancy as an example. This would free women from the burden of carrying the child and thus contribute to gender equality ${ }^{69}$. With its blessings equally distributed, technology will free us from the mechanisms of natural selection. Yet if humanity should fail to accomplish this «revolution», our species may face extinction, Carbonell warns ${ }^{70}$.

Carbonell calls for the development of a «critical consciousness». Yet his agenda remains very vague, he hardly proposes any concrete sociopolitical measures. His firm belief in scientific progress and its benefits for society at large is startling. Ambivalent or outright negative consequences of «scientific progress», such as the destruction of the environment or weapons of mass-destruction are almost completely absent in his writings. This is most obvious in the case of the modern bio-medical sciences. His plea to create a «new species», for example by genetic engineering, inevitably

67. For an in-depth analysis of the popular science books of the three co-directors of the EIA, see Hochadel, Oliver. A Boom of Bones and Books. The «Popularization Industry» of Atapuerca and Human Origins Research in Contemporary Spain. Public Understanding of Science. 2013; 22 (5): 530-537.

68. Carbonell, n. 41.

69. Carbonell, Eudald; Sala, Robert. Aún no somos humanos. Propuestas de humanización para el tercer milenio. Barcelona: Quinteto; 2003, p. 77f; compare Carbonell, Eudald. El sexo social. Badalona: Ara Llibres; 2010, p. 128.

70. Carbonell, Eudald. La conciencia que quema. Madrid: Now Books; 2008, p. 174. 
has overtones of eugenics ${ }^{71}$. Carbonell does not stipulate how science and technology might guarantee «a better use of selection».

This idea of the «socialization of knowledge» is by no means a new idea but can be traced back well into the nineteenth century. Numerous authors advocated in different ways the enormous potential of science (popularization) for the reform of society. Myth, prejudice and dogma need to be overcome and replaced by scientific knowledge in order to realize justice and equality in our society. Without room for nuances and in a highly stereotypical manner, Carbonell consistently opposes science and religion ${ }^{72}$. He hardly ever questions science as such and does not reflect on his own position as an individual with a personal agenda.

\section{The media scientist}

Because the idea of the socialization of knowledge is central to Carbonell's socio-political agenda, he never considers popularization as a mere add-on but as an integral part of his work as a researcher - from the very beginning. He told me that he edited his first journal in 1969 and organized his first exhibition on archaeology in 1972 -when he was 16 and 19 years old respectively ${ }^{73}$. The intended audience of the AAG was always the general public. Already in the 1970s and 1980s Carbonell and his colleagues also tried to reach school children ${ }^{74}$. He pursued the same strategy with respect to Atapuerca:

«The impact of Atapuerca in science, in the media, in all areas of social life was a phenomenon that was created intentionally. The underlying strategy had the objective to build a team that could do research on human evolution in acceptable conditions» ${ }^{75}$.

It seems to me to be beyond doubt that the spectacular finds alone would not have been sufficient for the enormous funding the EIA receives. There is a feedback mechanism in place here: more funding from the mid-1990s and particularly from the late 1990s onwards led (at least in the

71. Carbonell; Sala, n. 69, p. 128f; also see p. 231.

72. Carbonell; Bellmunt, n. 8, p. 25-29, Carbonell; Sala, n. 69, p. 180-181.

73. Carbonell, n. 41.

74. Carbonell et al. 1988, teaching material at the end of book; Carbonell; Bellmunt, n. 8, p. 81.

75. Carbonell, Eudald. El nacimiento de una nueva conciencia. Barcelona: Ada; 2007, p. 106. 
case of Atapuerca) to more discoveries and scientific publications. These in turn could be mobilized by the popularization industry of the EIA to increase once more the visibility of the researchers, to help them to win prestigious awards, to attract sponsors and so on. Carbonell as one of the three co-directors of the EIA played a pivotal role to start and maintain the feedback mechanism between research, popularization and fundraising ${ }^{76}$.

Clearly, the need for financial support is an important but only one reason to seek public visibility, as Carbonell told me: «I always was very much aware of the importance of the media, that they were an instrument we had to make use of to connect us socially, therefore I will always try to have a good relation and good contact with the press» ${ }^{77}$.

Carbonell conceives of the media in a purely instrumental way in order to advance his agenda. When a journalist from El País asked Carbonell whether the media had treated his research well he responded with a straight yes. «El País, La Vanguardia, most of the bigger media have specialized journalists now. And each time they ask better questions. A lot has changed in this respect» ${ }^{78}$. And he told me that the media «always said what I think» ${ }^{79}$. In Josep Corbella from La Vanguardia Carbonell always had a reliable ally. The Catalan science journalist has written numerous articles on Atapuerca since the mid-1990s often focusing on Carbonell. On occasion Carbonell has written articles for national newspaper himself. Nowadays he writes two different blogs, one in Catalan and one in Spanish. The latter one appears on the website of the conservative (and anti-Catalanist) newspaper El Mundo, maybe not the first medium that comes to mind when you consider yourself a Marxist and a Catalanist ${ }^{80}$.

However, Carbonell's pretension to merely use the media as a loudspeaker for his agenda is hard to sustain. As numerous studies in the history of science have shown the relationship between (popularizing) scientists and the media need to be understood in a dynamic way. The flow of communication is never just unidirectional, that is to say from the researcher to the supposedly

\footnotetext{
76. In Hochadel, n. 63, p. 149-210, I treat at length of the relationship between the EIA and the media.

77. Carbonell, n. 41.

78. Román, Francisco José. Hay que experimentar en todos los ámbitos. El País. 27 Apr 2000.

79. Carbonell, n. 41.

80. See blocs.tinet.cat/blog/el-bloc-deudald-carbonell and www.elmundo.es/blogs/elmundo/ sapiens.
} 
ignorant public ${ }^{81}$. It goes both ways. Carbonell - like any other scientist does have to comply with the «logic» of the media in order to be heard.

This logic requires for example that information needs to be presented in an entertaining way. This is nicely illustrated by the archaeology reality TV-show called Sota Terra (Under the earth) broadcast by the Catalan television channel TV3 in 2010 and $2012^{82}$. A team of archaeologists has three days to carry out an excavation at a specific site, for example a Roman house in Barcelona or a battlefield from the Civil War in the Ebro delta. TV3 contracted Eudald Carbonell to play the part of the expert archaeologist. In one of the episodes a local radio station interviews Carbonell. The host of the radio show asks him whether he likes being called a «media archaeologist». Carbonell responds: the more mediatic the better because this contributes to socializing knowledge about human evolution ${ }^{83}$.

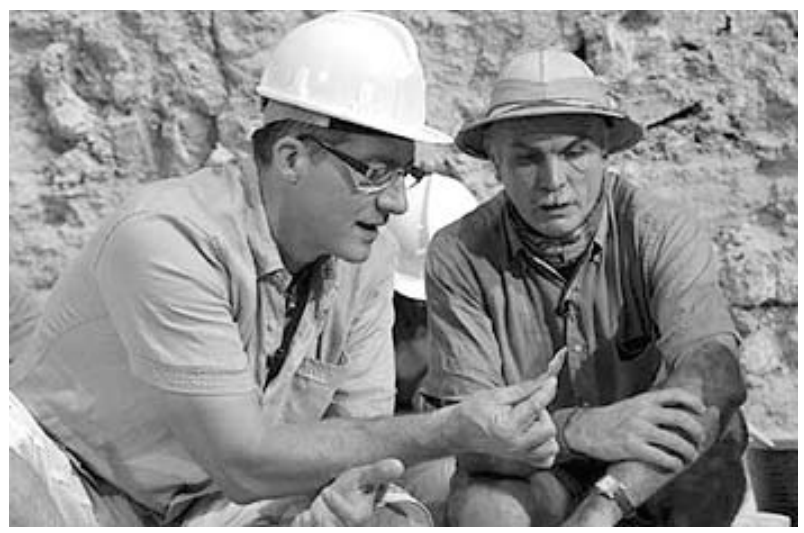

Figure 4. Eudald Carbonell with Fermí Fernández, presenter of the archaeology reality TV-show Sota Terra, 2010. Source: TV 3.

81. The latest overview and synthesis from a sociology of science point of view is Rödder; Franzen; Weingart, n. 5. For a good synthesis from a more historical perspective see Nieto-Galan, Agustí. Los públicos de la ciencia. Expertos y profanos a través de la historia. Madrid: Marcial Pons; 2011, in particular chapter 5.

82. The format for this program has been developed by the BBC's Channel 4. The original series is called Time Team and was on air in the UK between 1994 and 2013, see Holtorf, Cornelius. Archaeology is a brand! The meaning of archaeology in contemporary popular culture. Oxford: Archaeopress; 2007, p. 39-44.

83. Sota Terra, episode «Camp dels ninots», TV3, 19.7.2010, 31.25 min. 
While it may be difficult to assess in how far Sota Terra actually contributes to Carbonell's socio-political agenda it is more than obvious that TV3 banks on the fact that he is very well known in Catalonia. In a review of the series La Vanguardia hails Carbonell as «our national archaeologist» ${ }^{84}$. His scientific reputation vouched for the seriousness of the program. In fact, Carbonell has been commodified ${ }^{85}$. In its advertising of Sota Terra TV3 used very prominently his face and not least his sun-helmet. This clearly alludes to the well-defined appearance of the archaeologist adventurer and not to a researcher arguing for the reform of society. In the media the Hollywood character of Indiana Jones is the inevitable point of reference in numerous articles on Carbonell.

However, Sota Terra is only the most striking example of turning Carbonell into a promotional «product» that is recognizable. For many years he - and his distinct physiognomy - has already been an icon of the Atapuerca popularization industry. In its most reduced form a visitor of the site can buy him as a comic figure with pipe and pickaxe on a postcard (figure 1). With Cinta Bellmunt he has an experienced communicator at his side, El Mundo contracted him as a regular contributor and universities and museums may book him as a speaker for a negotiable fee. Publishers want to sell books with the «trademark» Carbonell. On the back cover of one of his essays he is hailed as the Catalan scientist with the most prestige internationally ${ }^{86}$.

It may be useful to compare Carbonell with what Declan Fahy has labeled the «celebrity scientist». His collective case study includes the four British scientists Stephen Hawking, Richard Dawkins, Susan Greenfield and James Lovelock. To start with the obvious differences: Carbonell -as a public figure - is virtually unknown abroad. And the visibility he has within Spain is not primarily owed to his popular science books but to the fame of the Atapuerca project. Yet the parallels are numerous: just as in the case of the British scientists Carbonell's «cultural authority» is based on his «scientific credentials». Just like Dawkins or Hawking he has «achieved wide cultural appeal through popularisation». Carbonell conceives of himself as a spokesperson of science and has «engaged in socio-cultural criticism, based on» his «largely scientistic world view». In his case too we detected

\footnotetext{
84. Amela, Victor-M. Memoria bajo tierra. La Vanguardia. 20 Jun 2010: 11.

85. Compare Fahy, n. 4, p. 245, 247.

86. Carbonell, n. 74.
} 
a clear «lack of historical reflection» in his understanding of science which appears as «progressive, cumulative and cerebral» ${ }^{87}$.

At the same time Carbonell presents himself in public as slightly eccentric, driven by a mission, equipped with an unruly mind and guided by intuition $^{88}$. Despite many years of searching in vain his belief that the EIA would eventually discover hominid fossils in Atapuerca never failed him: «I felt it, in some way I knew it» ${ }^{89}$. As Fahy says about the celebrity-scientists: «Their high-profile meant ideas, issues and ideologies of science have been refracted through the prism of their personalities» ${ }^{90}$.

\section{Catalanist and «interdependentist»}

Carbonell is the only Catalan among the three co-directors of the EIA. In his autobiography he describes his time as a member of a group of excursionists in the Pyrenees around 1970, i.e. in the last years of the dictatorship: «We used these excursions to exert Catalanism. This was at a time when our language, Catalan, was still prohibited or frowned upon in daily activities» ${ }^{91}$. He writes his popular science books in Catalan, his native tongue first, which are in most cases immediately translated into Spanish. The Catalan originals of his essays sell many more copies than the translations into Spanish. This is a clear indication that Carbonell's readers are mainly Catalans ${ }^{92}$.

As discussed above his early work clearly has to be seen in the political context of the time, i.e. the end of the dictatorship and the transition to democracy. In the way the AAG framed and practiced prehistoric archaeology it was part and parcel of asserting one's national identity as a Catalan. Carbonell has always argued in favor of Catalan self-determination. Yet his version of Catalanism is inextricably linked with his socio-political program sketched above. His most recent book that appeared in 2011 is entitled

\footnotetext{
87. Fahy, n. 4, p. 245-259, quotes p. 245, 248, 252.

88. Amela, Victor-M. Un día dejaremos de ser humanos. La Vanguardia. 29 Jul 2001: 6-7; Corbella, Josep. El arqueólogo se confiesa. La Vanguardia (Vivir). 24 Mar 2003: 9.

89. Cervera, José. El primer europeo. El País Semanal. 27 Aug 1995: 10-18, p. 18.

90. Fahy, n. 4, p. 246.

91. Carbonell; Bellmunt, n. 8, p. 60.

92. Hochadel, n. 67.
} 
Catalanisme evolutiu (co-authored with Cinta S. Bellmunt). Evolutionary Catalanism? What does this mean?

His Catalanisme evolutiu may be read as an «internal» dialogue between a Catalanist and scientist asserting his belief in reason and techno-scientific progress. There is no «natural» essence of a Catalan people. National identity needs to be thought in a way that allows e.g. for the integration of immigrants. Due to his anti-essentialist position Carbonell struggles to identify what may be specific to Catalonia and the Catalan people. He only mentions the most obvious elements such as the Catalan language and the history of Catalonia, in particular Franco's oppression. In fact, he is much more concerned with the «humanization» of society than with strictly political questions. Time and again he points to the central role of science and technology as the key to progress and social justice. He writes that his Catalanism is neither «nationalist» nor «independentist». Carbonell's key term instead is «interdependence», which may imply a «free alliance» with Spain and envisages a Europe of «interdependent peoples» ${ }^{93}$. However, in this book too Carbonell remains vague when it comes to propose a concrete political agenda. The concept of «interdependence» and of a "post-nationalist» state echoes ideas of the Catalan philosopher Xavier Rubert de Ventós and the politician Pasqual Maragall ${ }^{94}$.

To resume: Carbonell's three political roles we have identified may seem to be incompatible with one another. He describes himself as a «heterodox communist», he advocates Catalan self-determination and as co-director of the EIA he stages himself as a promoter of «Spanish science». Yet there is no contradiction here, Carbonell insisted when I interviewed him. He calls himself «Catalanist» but «antinationalist» and «interdependentist» ${ }^{95}$.

\section{Conclusion: from outsider to celebrity scientist}

In this article we have identified more than half a dozen roles that Carbonell assumed in the course of his career. In this conclusion I will try to show how they are connected. A crucial common denominator of many of his roles is

\footnotetext{
93. Carbonell; Bellmunt, n. 66, p. 53, 59.

94. Rubert de Ventós, Xavier. Catalunya: de la identitat a la independència; pròleg de Pasqual Maragall. Barcelona: Empúries; 1999; see in particular p. 130, 146, 154.

95. Interview Carbonell, n. 41.
} 
a center-periphery relationship. Carbonell perceived himself as being at the periphery in at least four ways: scientifically (1) as a young archaeologist in opposition to a conservative «academic establishment» in Catalonia in the 1970s fighting hard to have the ideas of the AAG about the existence of a Lower Paleolithic in Catalonia accepted; and (2) from the 1980s onwards as a Spanish scientist «overcoming» the dominance of foreign scholars. Politically he portrays himself (3) as a Catalanist confronting the Spanish «center» and (4) as communist overcoming social hierarchies.

Declaring oneself to be peripheral always was - not only but alsoinstrumental. It helped Carbonell to form his professional identity as an archaeologist. The «center», the «academic establishment», the «foreigners» appear to a large degree constructed. This became particularly obvious with respect to the alleged resistance against the claim of the AAG that Catalonia had been populated since prehistoric times. The case is similar with respect to the struggle against «scientific colonialism». It is true that the influence in particular of French prehistorians lasted mutatis mutandis from the late nineteenth to the late twentieth century. However, at the same time this «foreign threat» was also always part of a discourse in order to generate support for prehistoric research from institutions and the general public, to professionalize the national community and not least to provide an identity as a Spanish scholar.

The construction of Carbonell's roles is based on recurring narratives such as «fighting the establishment», overcoming «dogmatic» science (the claim of the non-existence of a Lower Paleolithic in Catalonia or the paradigm of a short chronology for the settlement of Europe), breaking new ground and shaping a national scientific community, be it Catalan or Spanish. In the last forty years, Carbonell has morphed from a young "peripheral» scholar into a figurehead of Catalan science. He has transformed himself from an underdog of a «scientifically colonized country» into a champion of Spanish science, building a strong national scientific community. In 2014, the Seventeenth Congress of the International Union of Prehistoric and Protohistoric Sciences will be hosted in Burgos. This time Carbonell himself will be the scientific secretary, as was de Lumley in 1976.

Carbonell proved «flexible» enough to take on new roles without (entirely) shedding the old ones. He is still a Catalanist, despite his advocacy of Spanish science. He still claims to be a communist although he has not been active in party politics for a long time. His concept of «socialization of knowledge» allows him to canvass for a fundamental reform of society 
and to conceive of his own research as political. This political pretension expresses itself for example in the name of his research institute in Tarragona: Institut Català de Paleoecologia Humana i Evolució Social. However, since the late 1990s Carbonell can hardly portray himself as an outsider anymore. His academic credentials in terms of publications have soared, and as the co-director of the EIA he wields considerable institutional power. And -if not in the whole of Spain then definitely in Catalonia- he has become highly visible in the public sphere.

There are two ways of reading his iconic sun-helmet. For Carbonell himself his headgear is actually a double homage: to Pere Bosch-Gimpera (1891-1974), an eminent Catalan archaeologist who was active in Catalan politics in the Second Republic and died in exile in Mexico, and to the Vietnamese soldiers led by general Võ Nguyên Giáp in their victorious battle against the US Army ${ }^{96}$. So for Carbonell his sun-helmet is a statement uniting Catalan archaeology, progressive politics and communism. Yet in the public sphere his sun-helmet - and this is the second and far more compelling way of reading it - has become an icon of marketing, the badge of a scientist-adventurer and Carbonell himself as a celebrity and thus a commodity. Carbonell cannot escape the inherent contradictions of the increasing medialization of science, that is to say the incompatibilities of his self-understanding as a critical scientist and the demands of the media and the cultural industries.

\section{Acknowledgments}

I thank the three referees for their numerous suggestions and constructive criticism. I also thank Miquel Carandell, Clara Florensa, Agustí Nieto-Galan, José Pardo-Tomás, Eduard Riu-Barrera and Assumpció Vila for their helpful and encouraging feedback. 